\title{
Stable Isotope Analysis and Persistent Organic Pollutants in Crustacean Zooplankton: The Role of Size and Seasonality
}

\author{
Roberta Piscia ${ }^{1, *(1)}$, Michela Mazzoni ${ }^{1,2}$, Roberta Bettinetti ${ }^{1,2}{ }^{(D)}$, Rossana Caroni ${ }^{1}$, \\ Davide Cicala ${ }^{1}$ and Marina Marcella Manca ${ }^{1}$ (D) \\ 1 Water Research Institute-National Research Council, IRSA-CNR, Largo Tonolli 50, 28922 Verbania, Italy \\ 2 DiSUIT, Department of Human Sciences and Innovation for the Territory, Via S. Abbondio 12, \\ 22100 Como (CO), Italy \\ * Correspondence: roberta.piscia@irsa.cnr.it; Tel.: +39-0323-518300
}

Received: 12 June 2019; Accepted: 14 July 2019; Published: 18 July 2019

\begin{abstract}
Zooplankton is crucial for the transfer of matter, energy, and pollutants through aquatic food webs. Primary and secondary consumers contribute to the abundance and standing stock biomass, which both vary seasonally. By means of taxa- and size-specific carbon and nitrogen stable isotope analysis, the path of pollutants through zooplankton is traced and seasonal changes are addressed, in an effort to understand pollutant dynamics in the pelagic food web. We analyzed zooplankton plurennial changes in concentration of polychlorinated biphenyls (PCBs) and dichlorodiphenyltrichloroethane and its relatives (DDTs) and in taxa-specific $\delta^{15} \mathrm{~N}$ signatures in two size fractions, $\geq 450 \mu \mathrm{m}$ and $\geq 850 \mu \mathrm{m}$, representative of the major part of zooplankton standing stock biomass and of the fraction to which fish predation is mainly directed, respectively. Our work is aimed at verifying: (1) A link between nitrogen isotopic signatures and pollutant concentrations; (2) the predominance of size versus seasonality for concentration of pollutants; and (3) the contribution of secondary versus primary consumers to carbon and nitrogen isotopic signatures. We found a prevalence of seasonality versus size in pollutant concentrations and isotopic signatures. The taxa-specific $\delta^{15} \mathrm{~N}$ results correlated to pollutant concentrations, by means of taxa contribution to standing stock biomass and $\delta^{15} \mathrm{~N}$ isotopic signatures. This is a step forward to understanding the taxa-specific role in pollutant transfer to planktivores and of zooplankton enrichment in PCBs and DDTs.
\end{abstract}

Keywords: stable isotope analysis; persistent organic pollutants; crustacean zooplankton; freshwater; size fractions; seasonality

\section{Introduction}

In lakes, crustacean zooplankton are low-order consumers and represent an important link between the base of the pelagic food web and the organisms at higher trophic levels, which may have economic or conservation value. Although considered a homogeneous compartment, zooplankton is composed of organisms that differ substantially from each other not only in their taxonomy, but also in body size, metabolic rate, and ecological roles [1]. While heterogeneity of the zooplankton community has been fairly well-documented in basic ecological studies, it is often overlooked in ecotoxicological ones, particularly in models, which are usually focused mainly on sources and top-levels of pollution patterns, the latter being directly related to human health. In particular, it is a crucial step in the flow of pollutants through aquatic ecosystems [2-5]. Both these pathways are involved, because zooplankton is directly related to primary producers and is able to process organic matter to feed on phytoplankton and to actively contribute to the microbial loop [6,7]. Zooplankton also 
represents a food source for all fish types at the larval stage and for zooplanktivorous fish at the adult stage $[8,9]$. Predation by fish and vertebrates is, in general, visual, therefore depending on prey size and visibility [10]. Both primary and secondary consumers may contribute to standing stock biomass in each size fraction considered. The contribution of primary and secondary consumers to zooplankton standing stock biomass generally varies with the season in deep, temperate, subalpine lakes, such as Lake Maggiore. In deep, temperate lakes, earlier spring warming and conditions of thermal water stratification influenced by climate change promote an early spring peak in phytoplankton biomass, followed by a peak in zooplankton biomass, mainly due to primary consumers, after about one month. The subsequent slow decline of zooplankton primary consumers is concomitant with an increasing contribution of zooplankton secondary consumers to the total zooplankton biomass in late summer. This pattern of change in zooplankton community composition also includes a change in organism size; in fact, a prevalence of larger sizes is observed when the contribution of predatory zooplankters increases.

Lake Maggiore has a long history of severe pollution brought about by persistent organic pollutants, such as dichlorodiphenyltrichloroethane and its metabolites. The International Commission for the Protection of the Italian-Swiss Common Waters (CIPAIS) supports monitoring activities in this lake, with a particular focus on priority substances, such as DDx and other organic chemicals of industrial origin, such as polychlorinated biphenyls (PCBs) and polybrominated diphenyl ethers (PBDEs), known for their harmful effects on human health and on environment [11,12]. Changes in physical and chemical conditions may cause their partial release into the dissolved phase, with increased bioavailability for organisms [13]. Because of their physico-chemical properties, persistent organic pollutants (POPs) can be detected everywhere, including worldwide remote regions far away from emission sources, such as polar or Alpine ecosystems [14-17]. In this study, we analyzed the seasonality of zooplankton in relation to persistent organic pollutant concentrations (i.e., DDTs and PCBs) in two different size fractions, one representative of most zooplanktonic biomass $(\geq 450 \mu \mathrm{m})$ and the other representative of fish food source $(\geq 850 \mu \mathrm{m})$. The former is representative of the major part of the crustacean zooplankton, while the latter represents the size fraction to which fish predation is mainly directed $[10,18]$. Despite its importance, zooplankton body size is usually neglected in studies on trophic pollutant transfer. Both seasonality and size are expected to drive zooplankton pollutant concentration over the season and a proper biomass estimation is essential to determine whether there is a prevalence of either of the two drivers. Furthermore, in order to study the modifications in the food web, we used carbon and nitrogen stable isotope analysis $\left({ }^{13} \mathrm{C},{ }^{15} \mathrm{~N}\right.$; SIA). By this method, food sources (e.g., littoral versus pelagic, deep versus shallow) can be clearly identified in a system, as can the time-specific contribution of organisms to food webs. The method was originally applied to marine environments and to fish in particular, not least for fingerprinting their origin. Only recently it has been increasingly applied in freshwater environments, not only regarding fish or other organisms of direct human consumption, but also regarding those which sustain their production and growth, thus allowing for a more reliable reconstruction of the food web [19]. SIA is applied to investigate ecosystems in the making, but also to predict, by means of organism nitrogen isotopic signature, timeand space-specific trophic position, from which, among others, biomagnification depends [20-22]. The trophic role and food sources of organisms can be evaluated by carbon and nitrogen stable isotope analysis [23-25]. Isotopic signatures provide information on the resources exploited by a consumer within an environment and its trophic positions in the food web [24,26]. In particular, the isotopic carbon signature is almost constant between food source and consumer, whereas a nitrogen isotopic enrichment is observed with an increase of the trophic status [27]. In the present work, we related the trophic role of zooplankton with persistent organic pollutant (POPs) concentrations in Lake Maggiore (northern Italy). Previous long term studies in this deep, large Italian lake suggested that zooplankton seasonal dynamics and the different primary and secondary consumer contributions to zooplankton biomass are reflected by different contributions of the two important native predatory cladocerans (Bythotrephes and Leptodora), of diaptomids and cyclopoid copepods, and of the cladoceran Daphnia. 
Our purpose is to investigate, in particular, how DDTs and PCBs vary with the season and in the two different size fractions, the former representing the bulk of crustacean zooplankton biomass and the latter representing the size fraction on which fish predation is mainly oriented. We hypothesize that variations are related to changes in $\delta^{15} \mathrm{~N}$ signature of the two fractions and that the latter results from the taxa-specific contribution to zooplankton biomass. We expect to find a correlation between taxa-specific signatures and taxa contribution to measured zooplankton standing stock biomass.

\section{Study Site}

Lake Maggiore is the second deepest $\left(\right.$ Depth $_{\max }=370 \mathrm{~m}$ ) and largest (area $=212 \mathrm{~km}^{2}$, volume $37.5 \mathrm{~km}^{3}$ ) subalpine lake located in the northwestern part of Italy (Figure 1). By its nature oligotrophic, the lake underwent eutrophication during the 1960s and 1970s. The eutrophication reversal and the return to oligotrophic conditions were due to a reduction in total phosphorus discharge into the lake after wastewater treatment facilities were opened and thanks to the ban of phosphorus-containing detergents.

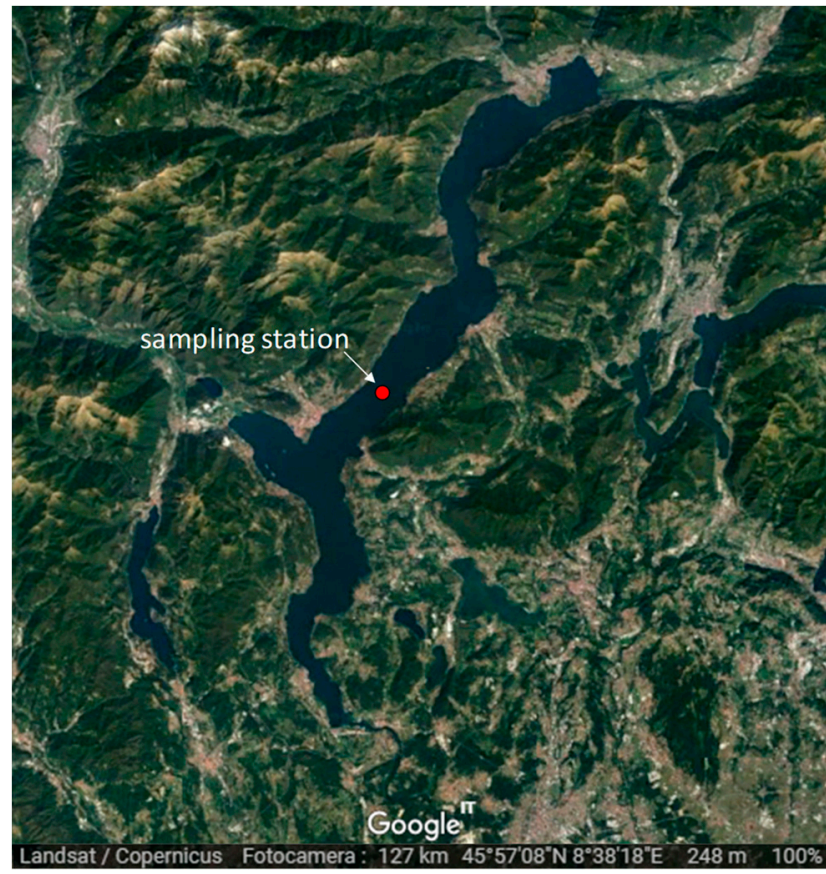

Figure 1. Map of Lake Maggiore. Sampling station location is shown with the red dot (from Google Earth).

Since 1996, contamination by dichlorodiphenyltrichloroethane and its relatives (DDTs), produced by a farm plant located in the lake catchment basin was detected [28]. Polychlorinated biphenyls (PCBs) in a steady-state condition were also reported [29-32].

Lake Maggiore is one of the best-studied lakes in Italy, with the first ecological research, including studies on zooplankton population dynamics, dating back to the early 1900s [33,34]. Long-term studies on zooplankton seasonal dynamics have been conducted over the last ten years by $\mathrm{C}$ and $\mathrm{N}$ stable isotope analyses, aimed at identifying trophic interactions and taxa-specific roles in the transfer of matter and pollutants within the pelagic food web.

\section{Materials and Methods}

Zooplankton sampling was performed seasonally at Ghiffa station ( $45^{\circ} 57^{\prime} \mathrm{N} ; 8^{\circ} 38^{\prime}$ E; Figure 1 ) in correspondence with the lake's deepest area $(370 \mathrm{~m})$. We collected two samples every day using two zooplankton nets that were $58 \mathrm{~cm}$ in diameter $(450 \mu \mathrm{m}$ and $850 \mu \mathrm{m}$ in mesh size), which were hauled from 0 to $50 \mathrm{~m}$ deep several times in order to obtain a sufficient amount of organisms needed to perform the analyses $(\min =2, \max =15)$. The total volume filtered was approximately $26 \mathrm{~m}^{3}$ per zooplankton 
collection. Samples of the size fraction $\geq 450 \mu \mathrm{m}$ were collected from January 2012 to January 2016, while samplings of the size fraction $\geq 850 \mu \mathrm{m}$ started later (May 2013). All samples were collected in duplicate. Live organisms of one of the two samples were concentrated in a laboratory setting in approximately $1 \mathrm{~L}$ of lake water, frozen at $-20{ }^{\circ} \mathrm{C}$, and subsequently used for carbon $\left({ }^{13} \mathrm{C}\right)$ and nitrogen $\left({ }^{15} \mathrm{~N}\right)$ stable isotope analysis (SIA). One third of the second zooplankton sample was immediately fixed and preserved in $95 \%$ ethanol for microscopic analysis at $6.3 \times$. We calculated the biomass of the different taxa by way of length-weight regression equations $[35,36]$. On the basis of the taxa, zooplankton organisms were grouped into primary consumers (herbivores, i.e., Daphnia, Eubosmina, Diaphanosoma, and copepod diaptomids) and secondary consumers (predators, i.e., Bythotrephes, Leptodora, and copepod cyclopoids). The remaining portion of the second sample (two-thirds) was filtered on a $1.2 \mu \mathrm{m}$ pore glass-fiber-filter $\left(\mathrm{GF} / \mathrm{C}, 4.7 \mathrm{~cm}\right.$ of diameter) and then frozen at $-20^{\circ} \mathrm{C}$. As a consequence of using large net mesh sizes, rotifers and early developmental stages of crustacean zooplankton (i.e., the smallest body size organisms) and large phytoplankton colonies were not included in our samples. However, they are of only marginal importance for the purpose of our study, in which large zooplankton was regarded as an important link in the transfer of pollutants from primary producers to fish owing to selective predation on visible prey, particularly large-bodied zooplankton [37]. SIA was performed on pooled samples of the two size fractions $(\geq 450 \mu \mathrm{m}$ and $\geq 850 \mu \mathrm{m})$ and on the already-listed crustacean taxa present in sufficient amounts in the sample. Under the dissecting microscope, we pooled individuals of each taxon in order to reach the minimum dry weight (DW) of $2 \mathrm{mg}$ per sample (approximately 70-700 individuals depending on the biomass). Samples were oven-dried for $24 \mathrm{~h}$ at $60{ }^{\circ} \mathrm{C}$, before being homogenized and transferred into tin capsules of $5 \times 9 \mathrm{~mm}$ in size. The isotopic compositions of organic carbon and nitrogen were determined by Ján Veizer Stable Isotope Laboratory (Ottawa University, Ontario, Canada) following methods already described in Visconti and Manca [38]. Isotope ratios were expressed as parts per thousand (\%o) difference from a standard reference of PeeDee Belemnite for carbon and atmospheric $\mathrm{N}_{2}$ for nitrogen, according to the equation:

$$
{ }^{13} \mathrm{C},{ }^{15} \mathrm{~N}=\left[\left(\frac{\mathrm{R}_{\text {sample }}}{\mathrm{R}_{\text {standard }}}\right)-1\right] \times 1000
$$

where $\mathrm{R}$ is the isotopic ratio ${ }^{13} \mathrm{C} /{ }^{12} \mathrm{C}$ and ${ }^{15} \mathrm{~N} /{ }^{14} \mathrm{~N}$.

For determination of organic compounds (OCs), the materials and methods described in Mazzoni et al. [1] were followed. Quantitative DDT homologue analyses were performed by the external standard method using a solution containing $\mathrm{pp}^{\prime} \mathrm{DDT}, \mathrm{pp}{ }^{\prime} \mathrm{DDE}$, and $\mathrm{pp} \mathrm{p}^{\prime} \mathrm{DDD}$ as the reference standard, prepared from single pure compounds (Pestanal, Sigma-Aldrich, Steinheim, Germany) in iso-octane (Carlo Erba, pesticide analysis grade, Val de Reuil, France). Arochlor 1260 (Alltech, IL, USA), while the addition of PCB 28, 52, and 118, was used for PCB quantification. The analyzed congeners consisted of PCB 28, 52, 101, 118, 138, 149, 153, 170, and 180. The detection limit for each OC was $1 \mathrm{ng} \cdot \mathrm{g}^{-1}$ lipid weight (1.w.).

We used the software SigmaPlot 11.0 (version 11, Systat Software Inc., San Jose, CA, USA) to perform statistical analyses. After verifying that the datasets were normally distributed, we applied two-way ANOVA in order to identify which factor, size or seasonality, drove changes throughout the year.

\section{Results}

A strong seasonality characterized stable isotope data and zooplankton biomass composition. In Figures 2 and 3, we reported data of taxa/groups biomass percentage composition, $\delta^{13} \mathrm{C} \%$ and $\delta^{15} \mathrm{~N} \%$ o values and total crustacean biomass of the two size fractions analyzed ( $\geq 450 \mu \mathrm{m}$ and $\left.\geq 850 \mu \mathrm{m}\right)$. A remarkably higher isotopic carbon (or less depleted) signature in summer and a higher nitrogen signature in autumn and winter was observed in the samples of both size fractions. The most depleted carbon signatures in the fraction $\geq 850 \mu \mathrm{m}$ occurred with high relative abundance of primary consumers 
to total zooplankton biomass, concomitant to the spring peak or abundance of the cladoceran filter feeder Daphnia. In the $\geq 450 \mu \mathrm{m}$ fraction, where most depleted carbon signatures were recorded, cyclopoids and diaptomids were also important contributors to the total biomass, together with Cladocera filter feeders.

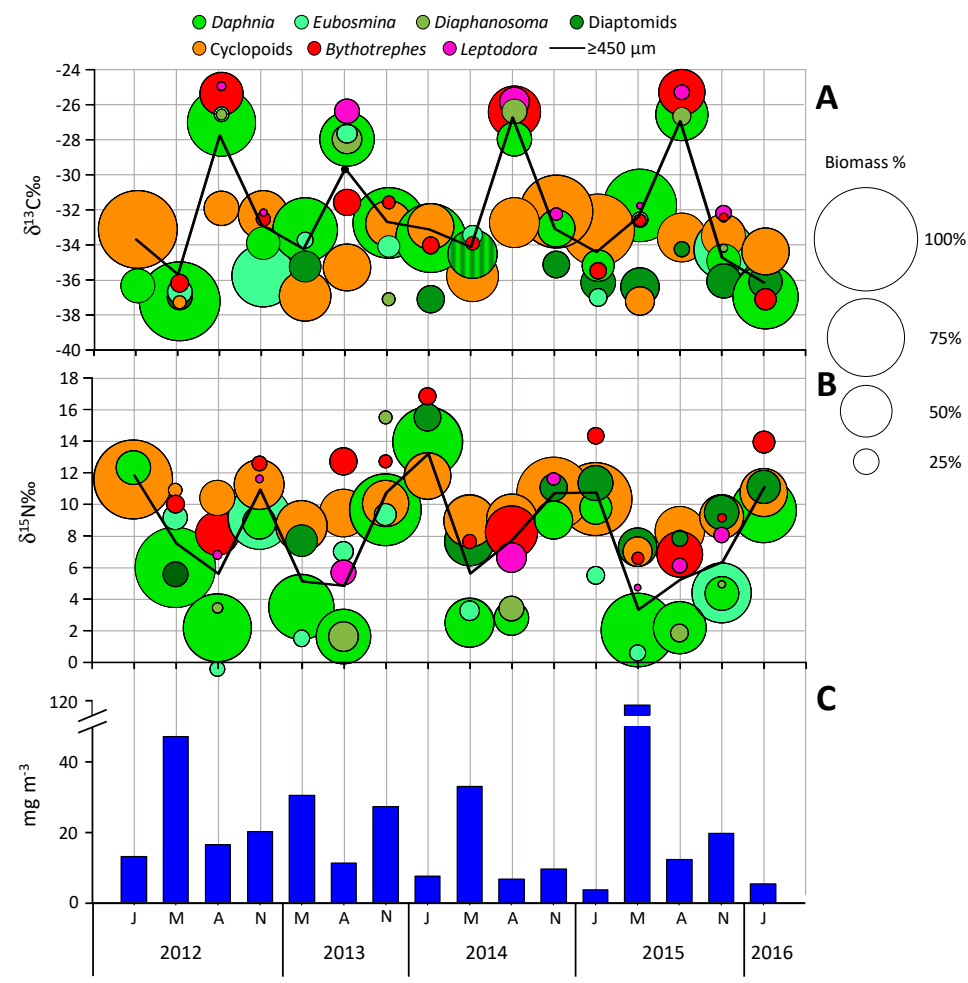

Figure 2. (A) Biomass percentage composition of planktonic crustacean taxa (bubbles) of Lake Maggiore and their $\delta^{13} \mathrm{C} \%$ o values (bubble centers) and $\delta^{13} \mathrm{C} \%$ values of pooled samples (black line); (B) biomass percentage composition of planktonic crustacean taxa (bubbles) of Lake Maggiore and their $\delta^{15} \mathrm{~N} \%$ o values (bubble centers) and $\delta^{15} \mathrm{~N} \%$ o values of pooled samples (black line); (C) total biomass of Lake Maggiore planktonic crustacean taxa. All data refer to the fraction $\geq 450 \mu \mathrm{m}$.

Zooplankton standing stock biomass largely changed with the seasons. In samples belonging to the $\geq 450 \mu \mathrm{m}$ size fraction, a spring peak was followed by a second phase of biomass increase in autumn. In the $\geq 850 \mu \mathrm{m}$ size fraction, peak biomass values were generally recorded in August. The unusual increase in May 2015 was related to the detection of the peak population growth of Daphnia. As already highlighted, Daphnia can be an important contributor to standing stock biomass, due to its peak biomass in spring being related to the development of young, smaller specimens.

We observed a clear seasonality of $\delta^{13} \mathrm{C}$ isotopic signatures for the $\geq 450 \mu \mathrm{m}$ size fraction during the studied years. The least depleted values in $\delta^{13} \mathrm{C} \%$ o were regularly measured in August, while more depleted values characterized the spring samples (May), when the contribution to the peak biomass of primary consumers, particularly Daphnia, was at its peak. Limited seasonal variation regarding the contribution to the total biomass was characteristic of the cyclopoid copepods, whose contribution to carbon and nitrogen isotopic signatures showed similar values during the year. In the $>450 \mu \mathrm{m}$ size fraction, cyclopoids and calanoids were related to depleted values of carbon isotope signatures and to the highest values of nitrogen signatures. The biomass contributions of different zooplankton taxa, both primary and secondary consumers, drove patterns of both isotopic signatures; therefore, the measured values, e.g., in January 2012, integrated isotopic signatures of the two taxa present, i.e., cyclopoid copepods and, to a lesser extent, Daphnia. 


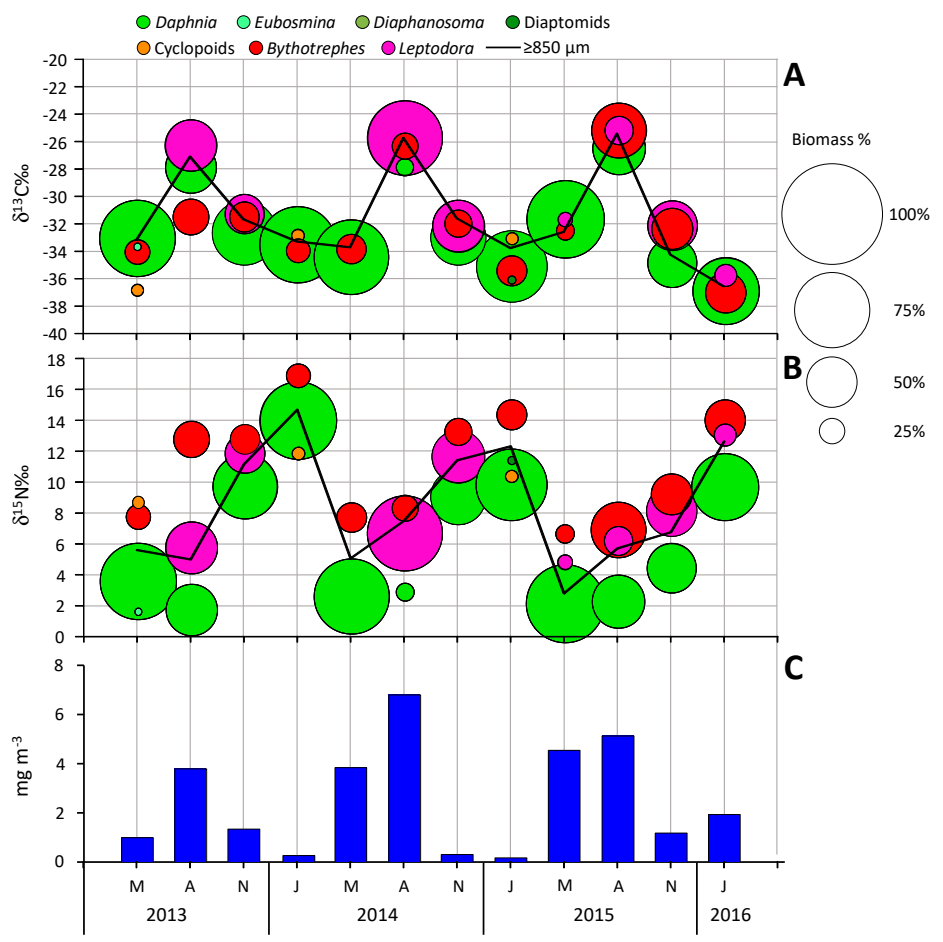

Figure 3. (A) Biomass percentage composition of planktonic crustacean taxa (bubbles) of Lake Maggiore and their $\delta^{13} \mathrm{C} \%$ o values (bubble centers) and $\delta^{13} \mathrm{C} \%$ o values of pooled samples (black line); (B) biomass percentage composition of planktonic crustacean taxa (bubbles) of Lake Maggiore and their $\delta^{15} \mathrm{~N} \%$ o values (bubble centers) and $\delta^{15} \mathrm{~N} \%$ o values of pooled samples (black line); (C) total biomass of Lake Maggiore planktonic crustacean taxa. All data refer to the fraction $\geq 850 \mu \mathrm{m}$.

A marked seasonality was also characteristic of the $\delta^{13} \mathrm{C}$ and $\delta^{15} \mathrm{~N}$ signatures in the $\geq 850 \mu \mathrm{m}$ size fraction. The least carbon-depleted values in August were related to the high contribution of secondary consumers, while more carbon-depleted values in spring and winter were related to a higher contribution of primary consumers. Values tended to be most enriched in winter, with secondary consumers more enriched than primary ones. The signatures of $\delta^{15} \mathrm{~N} \%$ o measured in the $\geq 850 \mu \mathrm{m}$ size fraction were related to the relative biomass contribution of primary and secondary consumers. Among predatory cladocerans, Bythotrephes was generally much more $\delta^{15} \mathrm{~N}$ enriched than Leptodora. For example, in August 2013, the nitrogen enrichment of Bythotrephes was higher in comparison to Leptodora and Daphnia. Differences in $\delta^{13} \mathrm{C}$ signatures suggest that Leptodora was living in deeper waters than Bythotrephes and Daphnia. Changes in isotopic signature and contribution to total biomass were mainly related to cladoceran primary and secondary consumers, thus enabling the investigation of infra-Cladocera food relationships.

As hypothesized, we found that carbon and nitrogen isotopic signatures of the two pooled size fractions could be reconstructed from taxa-specific signatures weighted on contribution to total biomass, by applying the following equation:

$$
\delta^{15} \mathrm{~N}, \delta^{13} \mathrm{C} \% o_{\text {pooled sample }}=(i \times \text { biomass } \%)_{\operatorname{taxon} 1}+\ldots . .+(i \times \text { biomass } \%)_{\text {taxon } \mathrm{N}},
$$

where $i=\delta^{15} \mathrm{~N} \%$ ond $\delta^{13} \mathrm{C} \%$ ore taxa-specific signatures.

Relationships between measured and estimated isotopic signatures were significant $\left(\delta^{13} \mathrm{C} \%\right.$ : $\mathrm{R}^{2}=0.904, \mathrm{~N}=28, \mathrm{~F}=244.682, P<0.001 ; \delta^{15} \mathrm{~N} \%$ o: $\mathrm{R}^{2}=0.942, \mathrm{~N}=28, \mathrm{~F}=438.413, P<0.001$; Figure 4). Such relationships are the result of the accuracy of estimation of both biomass and taxa-specific isotopic signatures. In fact, taxa-specific biomass estimation is based on length-weight regression equations applied to a consistent number of specimens (at least 25 specimens per taxa) and taxa-specific isotopic signatures analyses are based on a very high number of specimens (cfr. Section 3), which is necessary 
for Isotope Ratio Mass Spectrometry (IRMS) analysis (at least $1 \mathrm{mg}$ of dry weight). The accuracy of standing stock biomass determination from length-weight regression of taxa-specific analysis was also confirmed by the comparison with the direct biomass dry weight estimation, which was shown to be statistically significant $\left(\mathrm{R}^{2}=0.814, \mathrm{~N}=8, \mathrm{~F}=26.251 P=0.002\right)$.
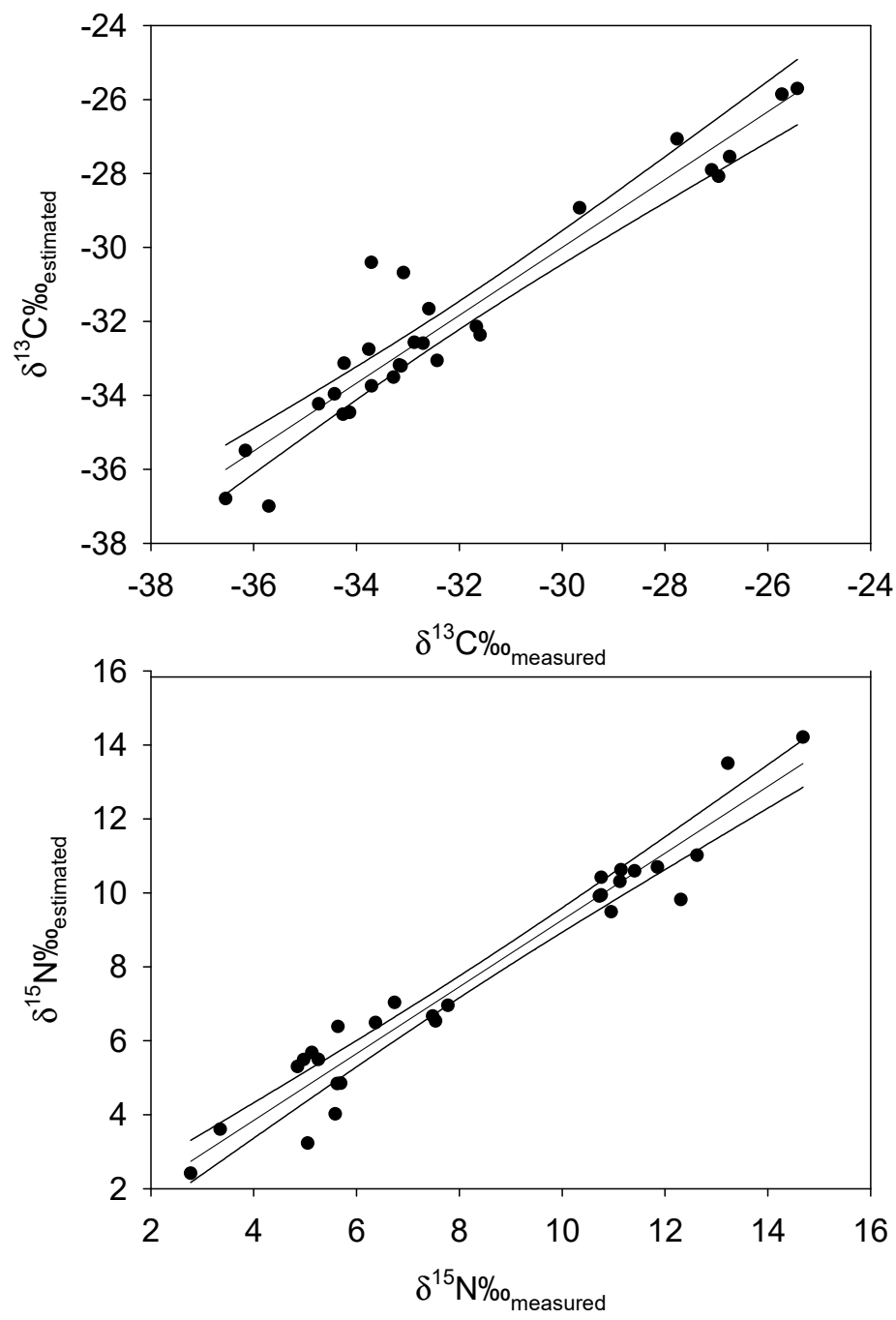

Figure 4. Relationship between isotopic fingerprint (carbon and nitrogen) of pooled zooplankton samples belonging to $\geq 450 \mu \mathrm{m}$ and $\geq 850 \mu \mathrm{m}$ size fractions determined by instrumental analysis (measured) and reconstructed values (estimated) following Equation (2).

The difference between the smaller and the larger size fraction was mainly determined by cladoceran taxa composition. In the case of DDTs, the main effects cannot be properly interpreted because a weak, but significant, interaction between size and seasonality was determined when two-way ANOVA was applied $(\mathrm{N}=28, \mathrm{~F}=3.149, P<0.048)$, so that the size of a factor's effect depends upon the level of the other factor. Changes in PCBs and $\delta^{15} \mathrm{~N}$ values were shown to be strongly driven by seasonality (PCB: $N=28, F=14.312, P<0.001 ; \delta^{15} \mathrm{~N}: \mathrm{N}=28, \mathrm{~F}=29.169, P<0.001$ ) and for both datasets there was no statistically significant interaction between factor size and seasonality $(P=0.181$ and $P=0.596$, respectively). Results of the two-way ANOVA are reported in Table 1.

A regression analysis was performed with $\delta^{15} \mathrm{~N}$ data and pollutant concentrations (Figure 5) with $\geq 450 \mu \mathrm{m}$ and $\geq 850 \mu \mathrm{m}$ size fractions. Changes in both DDT and PCB concentrations on a logarithmic scale were related to zooplankton $\delta^{15} \mathrm{~N} \%$ o isotopic signatures (DDTs: $\mathrm{R}^{2}=0.541, \mathrm{~N}=26, \mathrm{~F}=28,340$, $P<0.001 ;$ PCBs: $\left.\mathrm{R}^{2}=0.502, \mathrm{~N}=27, \mathrm{~F}=25.159, P<0.001\right)$. The data in the upper right side of the graph 
refer to autumn and winter samples, while those in the lower side of the graph are related to spring and summer samples.

Table 1. Results of the two-way ANOVA tests performed on DDTsPCBs concentrations and $\delta^{15} \mathrm{~N} \%$ o fingerprint of zooplankton samples of the two size fractions $(\geq 450 \mu \mathrm{m}$ and $\geq 850 \mu \mathrm{m})$.

\begin{tabular}{cccccc}
\hline & DF & SS & MS & F & P \\
\hline \multicolumn{5}{c}{ DDTs } \\
\hline Size & 1 & 3.672 & 3.672 & 58.456 & $<0.001$ \\
Season & 3 & 4.948 & 1.649 & 26.256 & $<0.001$ \\
Size X Season & 3 & 0.593 & 0.198 & 3.149 & 0.048 \\
\hline & \multicolumn{7}{c}{ PCBs } & & \\
\hline Size & 1 & 0.002 & 0.002 & 0.011 & 0.918 \\
Season & 3 & 8.550 & 2.850 & 14.312 & $<0.001$ \\
Size X Season & 3 & 1.052 & 0.351 & 1.760 & 0.187 \\
\hline & & $\mathbf{8} \mathbf{1 5} \mathbf{N o}$ & & & \\
\hline Size & 1 & 3.239 & 3.239 & 1.195 & 0.287 \\
Season & 3 & 7.226 & 79.075 & 26.169 & $<0.001$ \\
Size X Season & 3 & 5.229 & 1.743 & 0.643 & 0.596 \\
\hline
\end{tabular}
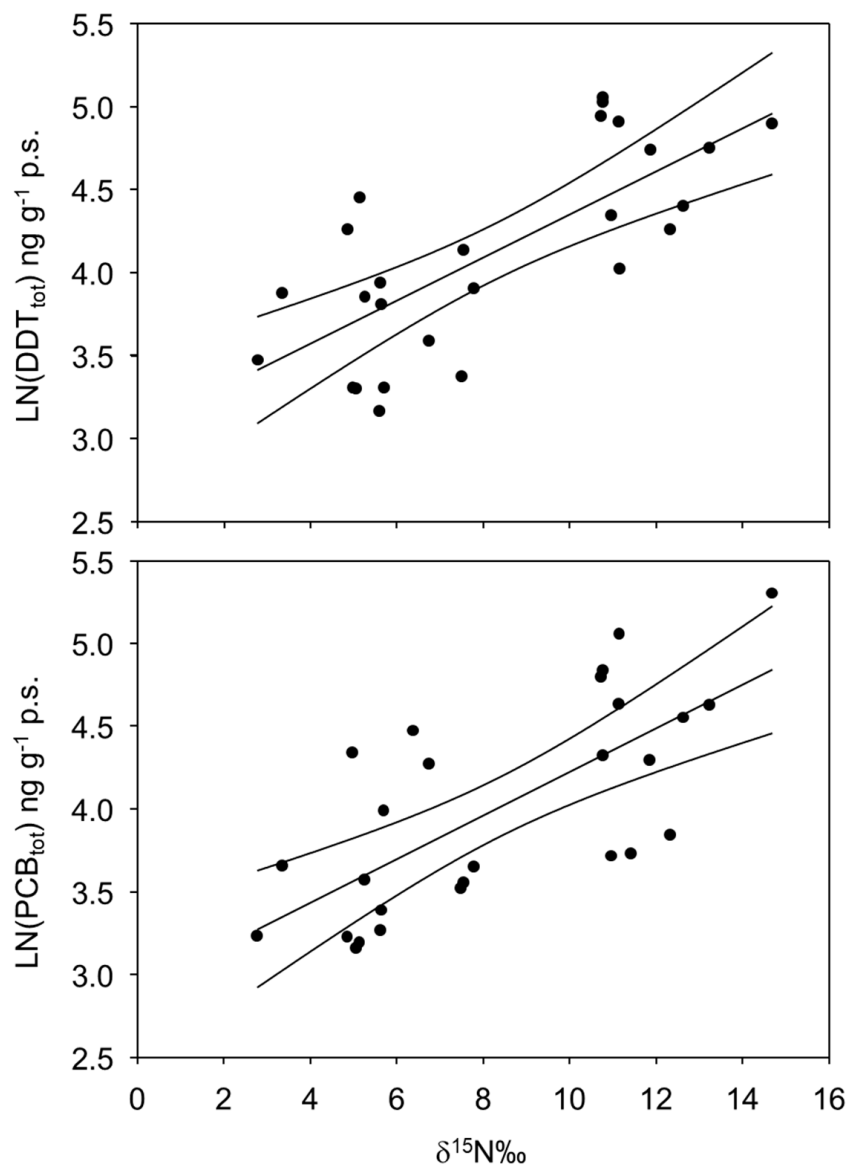

Figure 5. Relationship between nitrogen isotopic fingerprint of pooled zooplankton samples from Lake Maggiore, belonging to $\geq 450 \mu \mathrm{m}$ and $\geq 850 \mu \mathrm{m}$ size fractions, and persistent organic pollutant (POPs) concentrations, expressed as logarithmic scale.

POP concentrations in the $\geq 850 \mu \mathrm{m}$ size fraction were generally lower than in the $\geq 450 \mu \mathrm{m}$ size fraction (Figure A1). 


\section{Discussion}

The pelagic zooplankton is composed of a large variety of organisms differing in taxonomic composition and body size. Together, protists, monogonont rotifers, Cladocera, and Copepoda contribute to the zooplankton community, the latter with both individuals at their adult stage and a number of developmental stages that are different in size and trophic role. Regarding net zooplankton, as a result of the mesh size, only rotifers and crustaceans were reliably sampled. The former can be numerically dominant during the spring phase, along with naupliar and early copepodite stages of copepods. Their contribution to zooplankton biomass is little, however, with respect to Cladocera and adult or sub-adult copepods [38-40]. Altogether, the latter are $\geq 450 \mu \mathrm{m}$ in size.

Zooplanktivorous fish, however, tend to select larger $(\geq 850 \mu \mathrm{m})$ and more visible prey, such as Bythotrephes, large, ovigerous Daphnia, and Leptodora. Therefore, these are a component of the zooplankton population, which is active in transferring POPs to fish [10,41-44].

By choosing to focus on the two size fractions of crustacean zooplankton, we aimed to investigate components which are directly involved in the transfer of pollutants in the trophic chain. In addition, investigating the role of micro-zooplankton is almost impossible, given that POP concentrations and $\delta^{13} \mathrm{C}$ and $\delta^{15} \mathrm{~N}$ analyses require high weight amounts of zooplankton material (approximately $1 \mu \mathrm{g}$ dry weight and $1 \mathrm{mg}$ dry weight, respectively). Further studies are required to elucidate the role of micro-zooplankton as carrier of pollutants.

As expected, zooplankton biomass composition largely varied with the season in both size fractions analyzed, because in deep subalpine lakes, the abundance and composition of zooplankton populations vary along the season [45-47]. A spring peak abundance of phytoplankton population triggers the growth of primary zooplankton consumers, such as the large filter-feeder Daphnia, which, in Lake Maggiore, usually reaches its peak population density in May [47]. The increase of Daphnia and other primary consumer cladocerans (Eubosmina, Diaphanosoma) in spring is followed by an increase in predatory cladocerans (Bythotrephes and Leptodora), able to selectively exploit primary consumers and contribute to their decline [48,49]. In turn, the decrease in zooplankton primary consumers promotes a second phytoplankton peak in summer, which leads to a second phase of increase in primary consumers in autumn.

In this study, seasonality was also observed in isotopic carbon and nitrogen zooplankton signatures. In pelagic zooplankton, $\delta^{13} \mathrm{C} \%$ o tended toward less depleted values in summer, likely mirroring phytoplankton isotopic signatures $[38,39,50]$. During thermal stratification, the high growth rates of phytoplankton cells can lead to the consumption of dissolved atmospheric $\mathrm{CO}_{2}$, causing a shift in carbon exploitation sources toward the uptake of the $\mathrm{HCO}_{3}{ }^{-}$ion [51-54]. The unselective filter feeder Daphnia feeds on seston particles, which fit the distance between their intersetular filtering combs (i.e., $0.2-50 \mu \mathrm{m}$ ) [55]. Since Lake Maggiore seston is mainly composed of phytoplankton cells and carbon fractionation is negligible, Daphnia isotopic signature specimens matched variations of the phytoplankton carbon fingerprint $[45,50]$. The pelagic zooplankton nitrogen isotopic signature also varied with the season, with the maximum enrichment in winter. Isotopic nitrogen tended to increase along the trophic food chain and stepwise enrichment varied in different environments and with the structure of the trophic web $[45,56,57]$. Isotopic nitrogen enrichment is diet-dependent [58]. In eutrophic lakes, where high values of $\delta^{15} \mathrm{~N} \%$ ore usually found, zooplankton organisms do not feed only on phytoplankton, but also exploit alternative organic particulate matter, such as bacteria, protozoa, exuviae, and fecal pellets of zooplankton specimens, which are more $\delta^{15} \mathrm{~N}$-enriched than phytoplankton algae. We can hypothesize that, in winter, when the abundance of phytoplankton cells is low, alternative, $\delta^{15} \mathrm{~N}$-enriched food sources (e.g., bacteria, protozoa, exuviae) became more important, leading to the observed enrichment in isotopic nitrogen content. In addition, under food shortage conditions, the zooplankton might be able to exploit $\delta^{15} \mathrm{~N} \%$ o-enriched lipids which accumulate in high food concentration conditions $[59,60]$.

Distinguishing between primary and secondary consumers is crucial for the reconstruction of patterns of matter and energy through the pelagic food web. As primary and secondary consumers 
largely overlap each other in body size, such distinction cannot be based on size fraction analyses of zooplankton. We found that the isotopic signature of pooled zooplankton samples of the two size analyzed fractions was tightly related to taxa-specific contribution to total biomass, thus allowing for the identification of taxa-specific contribution to measured $\delta^{15} \mathrm{~N} \%$ o isotopic signatures. The latter is, in turn, correlated to POP concentrations, therefore allowing for a better definition of primary and secondary zooplankton consumer taxa in the transfer of toxicants through the pelagic food web. The significant relationship between pooled zooplankton samples and taxa-specific contributions to the total biomass in Lake Maggiore results from the fact that other zooplankton particles are excluded when samples are filtered through $450 \mu \mathrm{m}$ nets. In Lake Maggiore, detritus is usually $<126 \mu \mathrm{m}$ and the contribution of phytoplankton colonies $>76 \mu \mathrm{m}$ is largely negligible. Therefore, any other zooplankton contribution to the total biomass in the samples of the two size fractions analyzed was certainly negligible. This is not the case in eutrophic or mesotrophic lakes, where zooplankton is smaller and detritus and phytoplankton colonies can be found in zooplankton samples in non-negligible amounts [1,61].

We hypothesized that both size and seasonality can influence POP concentrations in zooplankton populations and that the two parameters are related to the $\delta^{15} \mathrm{~N} \%$ o isotopic signature. Our results highlighted a predominance of seasonality versus size. The $\geq 450 \mu \mathrm{m}$ fraction was composed of primary (Daphnia, Eubosmina, Diaphanosoma and diaptomids) and secondary consumers (cyclopoids, Bythotrephes and Leptodora) throughout the year, while in the $\geq 850 \mu \mathrm{m}$ fraction, the biomass of secondary consumers is dominant in August. As secondary consumers are expected to be higher in POP concentrations, we would have expected to record the highest values of POP concentrations in summer; on the contrary, we observed high POP concentrations in winter, when zooplankton nitrogen enrichment was at its maximum. In fact, the $\delta^{15} \mathrm{~N} \%$ and POP results directly correlated, with both tending to increase from spring to winter. Ecotoxicological studies on marine trophic chains demonstrated a similar relationship along the food chain [62,63]. In Lake Maggiore, the seasonal pattern of POP concentrations was very similar terms of values between years of the study period [28], suggesting a steady-state condition. In these conditions, the major $\delta^{15} \mathrm{~N}$-enrichment of carnivorous species was probably hidden by seasonal variations in $\delta^{15} \mathrm{~N} \%$, which was dependent on quality of organic particles, i.e., the bacteria, protozoa, or organic particles deriving from dead organisms should have higher POP concentrations than phytoplankton cells.

The predominance of seasonality versus size was confirmed also by DDT concentrations in the smallest size fraction. Theoretically, the big predators, Bythotrephes and Leptodora, and the largest Daphnia specimens of the $\geq 850 \mu \mathrm{m}$ size fraction should be characterized by higher values of POP concentrations, the former due to this specimen belonging to an upper trophic level and the latter because adults of a larger size can accumulate more pollutants in their tissues. However, our results likely reflect the fact that copepods rich in lipids (substance where POPs are mainly stored) were not present in the larger size fraction. However, because zooplanktivorous fish mainly select large cladocerans [43], the $\geq 850 \mu \mathrm{m}$ fraction should be more representative of fish food sources.

\section{Conclusions}

Zooplankton play a crucial activity in matter and energy transfer in the food web. In temperate lakes, biomass, taxa, and size composition largely vary with the season. The contribution of primary and secondary zooplankton consumers also varies seasonally, along with the $\delta^{15} \mathrm{~N} \%$ isotopic signature. By investigating seasonal changes in biomass and taxa-specific contributions and in carbon and nitrogen isotopic signatures along with DDT and PCB concentrations, we aimed at quantifying the relative importance of size versus seasonality. We found that the $\delta^{15} \mathrm{~N} \%$ o of two size fractions, representative of bulk crustacean zooplankton biomass and of the fraction on which fish mainly prey, respectively, significantly correlated to POP concentration, as both varied with the season. The bulk zooplankton nitrogen isotopic signature resulted from a biomass-weighted taxa-specific isotopic signature, thus enabling us to distinguish between the contributions of secondary and primary 
consumers to measured nitrogen enrichment, from which the concentration of pollutants depends. DDT concentration was higher in the $>450 \mu \mathrm{m}$ fraction, while no difference was found in PCB concentration in the two size fractions. The difference between the two was mainly related to copepod adults, which were entirely lacking in the larger, $>850 \mu \mathrm{m}$ size fraction, the one on which fish selectively prey. Overall, seasonality was largely predominant over size for the dynamics of DDTs and PCBs, therefore suggesting that, in temperate lakes, more than one time spot studies are required; indeed, multi-year studies are ideal for verifying, among others, the condition of a steady state which must be fulfilled before applying models regarding the transfer of pollutants through an ecosystem.

The oligotrophic, subalpine Lake Maggiore was ideal for investigating the role of zooplankton in pollutant transfer, as size spectra distinction allows for the neglect of background noise caused by micro-zooplankton, protists, and phytoplankton algae. This is not the case for more productive lakes, in which such size-based distinction cannot be applied in the same way.

Author Contributions: Formal analysis, M.M.M. and R.P.; SIA and zooplankton investigation, M.M.M. and R.P.; POPs investigations, M.M. and R.B.; writing—original draft preparation, M.M.M., R.P., R.C., and D.C.; Review, R.B. and M.M.

Funding: This research was funded by CIPAIS (Commissione Internazionale per la Protezione delle Acque Italo-Svizzere).

Conflicts of Interest: The authors declare no conflict of interest.

\section{Appendix A}

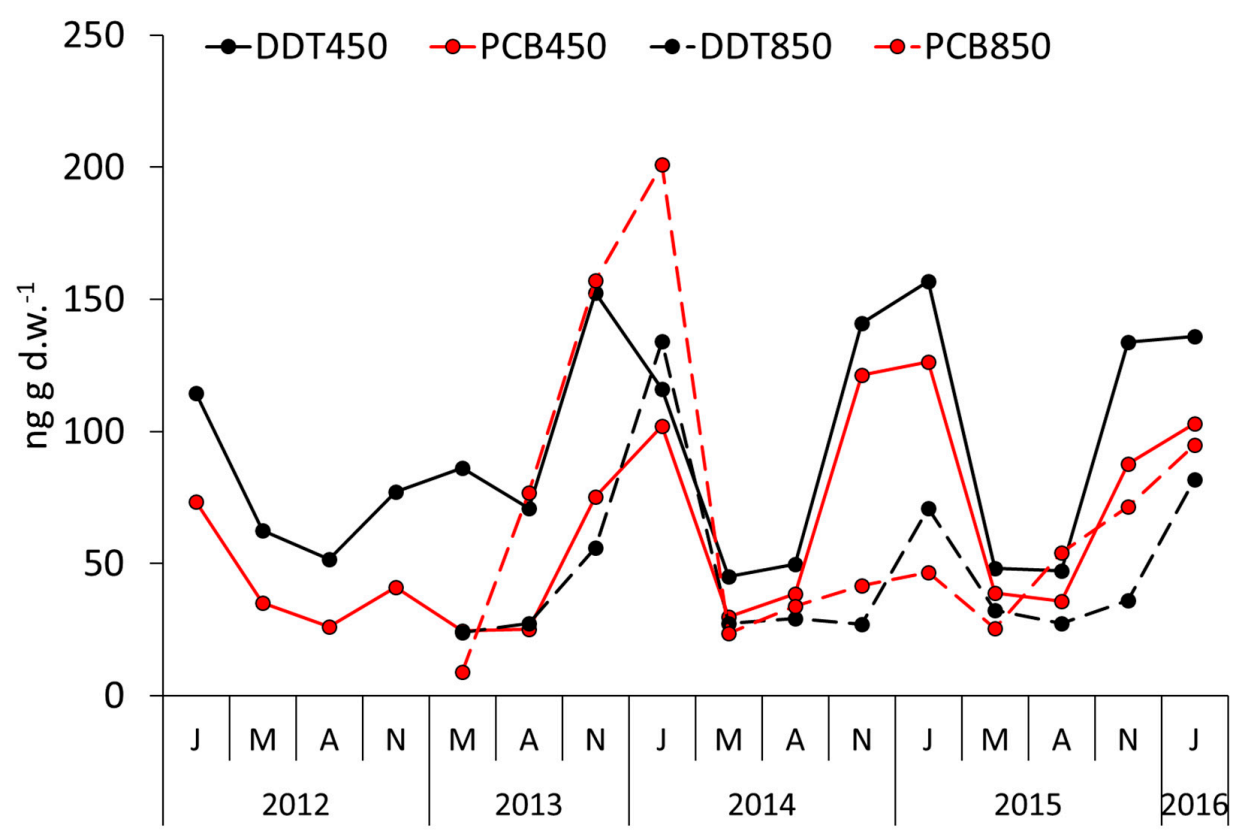

Figure A1. Concentration of POPs in two crustacean zooplankton size fractions $(\geq 450 \mu \mathrm{m}$ and $\geq 850 \mu \mathrm{m})$ of Lake Maggiore.

\section{References}

1. Mazzoni, M.; Boggio, E.; Manca, M.; Piscia, R.; Quadroni, S.; Bellasi, A.; Bettinetti, R. Trophic transfer of persistent organic pollutants through a pelagic food web: The case of Lake Como (Northern Italy). Sci. Total Environ. 2018, 640, 98-106. [CrossRef] [PubMed]

2. Bettinetti, R.; Manca, M. Understanding the role of zooplankton in transfer of pollutants through trophic food webs. In Zooplankton: Species Diversity, Distribution and Seasonal Dynamics; Kehayias, G., Ed.; Nova Science Publishers, Inc.: Hauppauge, NY, USA, 2013; pp. 1-18. 
3. Bettinetti, R.; Galassi, S.; Guzzella, L.; Quadroni, S.; Volta, P. The role of zooplankton in DDT biomagnification in a pelagic food web of Lake Maggiore (Northern Italy). Environ. Sci. Pollut. Res. 2010, 17, 1508-1518. [CrossRef] [PubMed]

4. Loseto, L.L.; Stern, G.A.; Ferguson, S.H. Size and biomagnification: How habitat selection explains beluga mercury levels. Environ. Sci. Technol. 2008, 42, 3982-3988. [CrossRef] [PubMed]

5. Forest, A.; Sampei, M.; Makabe, R.; Sasaki, H.; Barber, D.G.; Gratton, Y.; Wassmann, P.; Fortier, L. The annual cycle of particulate organic carbon export in Franklin Bay (Canadian Artica): Environmental control and food web implications. J. Geophys. Res. 2008, 113, C03S05. [CrossRef]

6. Peduzzi, P.; Herndl, G.J. Zooplankton activity fueling the microbial loop: Differential growth response of bacteria from oligotrophic and eutrophic waters. Limnol. Oceanogr. 1992, 37, 1087-1092. [CrossRef]

7. Zingel, P.; Agasild, H.; Karus, K.; Kangro, K.; Tammert, H.; Tõnno, I.; Tõnu, F.; Nõges, T. The influence of zooplankton enrichment on the microbial loop in a shallow, eutrophic lake. Eur. J. Protistol. 2016, 52, $22-35$. [CrossRef] [PubMed]

8. Confer, J.L.; Howick, G.L.; Corzette, M.H.; Kramer, S.L.; Fitzgibbon, S.; Landesberg, R. Visual predation by planktivores. Oikos 1978, 31, 27-37. [CrossRef]

9. Bandara, K.; Varpe, Ø.; Ji, R.; Eiane, K. Artificial evolution of behavioral and life history strategies of high-latitude copepods in response to bottom-up and top-down selection pressures. Progr. Oceanogr. 2019, 173, 134-164. [CrossRef]

10. de Bernardi, R.; Giussani, G.; Manca, M. Cladocera: Predators and prey. Hydrobiologia 1987, 145, $225-243$. [CrossRef]

11. Eljarrat, E.; Barcelo, D. Priority lists for persistent organic pollutants and emerging contaminants based on their relative toxic potency in environmental samples. TrAC Trends Anal. Chem. 2003, 22, 655-665. [CrossRef]

12. Ruiz-Fernández, A.C.; Ontiveros-Cuadras, J.F.; Sericano, J.L.; Sanchez-Cabeza, J.A.; Kwong, L.L.W.; Dunbar, R.B.; Mucciarone, D.A.; Pérez-Bernal, L.H.; Páez-Osuna, F. Long-range atmospheric transport of persistent organic pollutants to remote lacustrine environments. Sci. Total Environ. 2014, 493, 505-520. [CrossRef]

13. Pisanello, F.; Marziali, L.; Rosignoli, F.; Poma, G.; Roscioli, C.; Pozzoni, F.; Guzzella, L. In situ bioavailability of DDT and Hg in sediments of the Toce River (Lake Maggiore basin, Northern Italy): Accumulation in benthic invertebrates and passive samplers. Environ. Sci. Pollut. Res. 2016, 23, 10542-10555. [CrossRef]

14. Tremolada, P.; Villa, S.; Bazzarin, P.; Bizzotto, E.; Comolli, R.; Vighi, M. POPs in mountain soils from the Alps and Andes: Suggestions for a 'precipitation effect'on altitudinal gradients. Water Air Soil Pollut. 2008, 188, 93-109. [CrossRef]

15. Hung, H.; Kallenborn, R.; Breivik, K.; Su, Y.; Brorström-Lundén, E.; Olafsdottir, K.; Thorlacius, J.M.; Leppänen, S.; Bossi, R.; Skov, H.; et al. Atmospheric monitoring of organic pollutants in the Arctic under the Arctic Monitoring and Assessment Programme (AMAP): 1993-2006. Sci. Total Environ. 2010, 408, 2854-2873. [CrossRef]

16. van Drooge, B.; Garriga, G.; Koinig, K.; Psenner, R.; Pechan, P.; Grimalt, J. Sensitivity of a remote alpine system to the Stockholm and LRTAP regulations in POP emissions. Atmosphere 2014, 5, 198-210. [CrossRef]

17. Guzzella, L.; Salerno, F.; Freppaz, M.; Roscioli, C.; Pisanello, F.; Poma, G. POP and PAH contamination in the southern slopes of Mt. Everest (Himalaya, Nepal): Long-range atmospheric transport, glacier shrinkage, or local impact of tourism? Sci. Total Environ. 2016, 544, 382-390. [CrossRef]

18. Zhang, C.; Zhong, R.; Wang, Z.; Montaña, C.G.; Song, Y.; Pan, K.; Wang, S.; Wu, Y. Intra-annual variation of zooplankton community structure and dynamics in response to the changing strength of bio-manipulation with two planktivorous fishes. Ecol. Indic. 2019, 101, 670-678. [CrossRef]

19. Perga, M.E.; Gerdeaux, D. Seasonal variability in the $\delta 13 \mathrm{C}$ and $\delta^{15} \mathrm{~N}$ values of the zooplankton taxa in two alpine lakes. Acta Oecol. 2006, 30, 69-77. [CrossRef]

20. Hobson, K.A.; Fisk, A.; Karnovsky, N.; Holst, M.; Gagnon, J.M.; Fortier, M. A stable isotope $\left(\delta^{13} \mathrm{C}, \delta^{15} \mathrm{~N}\right)$ model for the North Water food web: Implications for evaluating trophodynamics and the flow of energy and contaminants. Deep Sea Res. Part II Top. Stud. Oceanogr. 2002, 49, 5131-5150. [CrossRef]

21. Bettinetti, R.; Quadroni, S.; Manca, M.; Piscia, R.; Volta, P.; Guzzella, L.; Roscioli, C.; Galassi, S. Seasonal fluctuations of DDTs and PCBs in zooplankton and fish of Lake Maggiore (Northern Italy). Chemosphere 2012, 88, 344-351. [CrossRef] 
22. Romero-Romero, S.; Herrero, L.; Fernández, M.; Gómara, B.; Acuña, J.L. Biomagnification of persistent organic pollutants in a deep-sea, temperate food web. Sci. Total Environ. 2017, 605, 589-597. [CrossRef]

23. Peterson, B.J.; Fry, B. Stable isotopes in ecosystem studies. Annu. Rev. Ecol. Syst. 1987, 18, 293-320. [CrossRef]

24. Post, D.M. Using stable isotopes to estimate trophic position: Models, methods, and assumptions. Ecology 2002, 83, 703-718. [CrossRef]

25. Minagawa, M.; Wada, E. Stepwise enrichment of ${ }^{15} \mathrm{~N}$ along food chains: Further evidence and the relation between ${ }^{15} \mathrm{~N}$ and animal age. Geochim. Cosmochim. Acta 1984, 48, 1135-1140. [CrossRef]

26. Inger, R.; Bearhop, S. Applications of stable isotope analyses to avian ecology. IBIS 2008, 150, 447-461. [CrossRef]

27. Piscia, R.; Boggio, E.; Bettinetti, R.; Mazzoni, M.; Manca, M. Carbon and Nitrogen Isotopic Signatures of Zooplankton Taxa in Five Small Subalpine Lakes along a Trophic Gradient. Water 2018, 10, 94. [CrossRef]

28. Guzzella, L.M.; Novati, S.; Casatta, N.; Roscioli, C.; Valsecchi, L.; Binelli, A.; Parolini, M.; Solcà, N.; Bettinetti, R.; Manca, M.; et al. Spatial and temporal trends of target organic and inorganic micropollutants in Lake Maggiore and Lake Lugano (Italian-Swiss water bodies): Contamination in sediments and biota. Hydrobiologia 2018, 824, 271-290. [CrossRef]

29. Nizzetto, L.; Gioia, R.; Li, J.; Borgå, K.; Pomati, F.; Bettinetti, R.; Dachs, J.; Jones, K.C. Biological pump control of the fate and distribution of hydrophobic organic pollutants in water and plankton. Environ. Sci. Technol. 2012, 46, 3204-3211. [CrossRef]

30. Riva, C.; Binelli, A.; Parolini, M.; Provini, A. The case of pollution of Lake Maggiore: A 12-year study with the bioindicator mussel Dreissena polymorpha. Water Air Soil Pollut. 2010, 210, 75-86. [CrossRef]

31. Guilizzoni, P. Indagini su DDT e sostanze pericolose nell'ecosistema del Lago Maggiore. In Rapporto Annuale 2012, Rapporto Finale 2008-2012; Commissione Internazionale per la protezione delle acque italo-svizzere, Ed.; C.N.R.-I.S.E. Sede di Verbania: Verbania, Italy, 2013; p. 151.

32. Volta, P.; Tremolada, P.; Neri, M.C.; Giussani, G.; Galassi, S. Age-dependent bioaccumulation of organochlorine compounds in fish and their selective biotransformation in top predators from Lake Maggiore (Italy). Water Air Soil Pollut. 2009, 197, 193-209. [CrossRef]

33. de Bernardi, R.; Giussani, G.; Manca, M.; Ruggiu, D. Long-term dynamics of plankton communities in Lago Maggiore (N. Italy). Verh. Int. Ver. Theor. Angew. Limnol. 1988, 23, 729-733. [CrossRef]

34. Ruggiu, D.; Morabito, G.; Panzani, P.; Pugnetti, A. Trends and relations among basic phytoplankton characteristics in the course of the long-term oligotrophication of Lake Maggiore (Italy). In Phytoplankton and Trophic Gradients; Springer: Dordrecht, The Netherlands, 1998; pp. 243-257.

35. McCauley, E. The estimation of the abundance and biomass of zooplankton in samples. In A Manual on Methods for the Assessment of Secondary Productivity in Fresh Waters; Downing, J.A., Rigler, F.H., Eds.; Blackwell Scientific Pubblication: Oxford, UK, 1984; Volume 17, pp. 228-265.

36. Manca, M.; Comoli, P. Biomass estimates of freshwater zooplankton from length-carbon regression equations. J. Limnol. 2000, 59, 15-18. [CrossRef]

37. Zaret, T.M. Predation and Freshwater Communities; Yale Univ. Press: New Haven, CT, USA, 1980; p. 187.

38. Visconti, A.; Manca, M. Seasonal changes in the $\delta^{13} \mathrm{C}$ and $\delta^{15} \mathrm{~N}$ signatures of the Lago Maggiore pelagic food web. J. Limnol. 2011, 70, 263-271. [CrossRef]

39. Visconti, A.; Volta, P.; Fadda, A.; Di Guardo, A.; Manca, M. Seasonality, littoral versus pelagic carbon sources, and stepwise ${ }^{15} \mathrm{~N}$-enrichment of pelagic food web in a deep subalpine lake: The role of planktivorous fish. Can. J. Fish. Aquat. Sci. 2013, 71, 436-446. [CrossRef]

40. Fadda, A.; Manca, M.; Camin, F.; Ziller, L.; Buscarino, P.; Mariani, M.; Padedda, B.M.; Sechi, N.; Virdis, T.; Lugliè, A. Study on the suspended particulate matter of aMediterranean artificial lake (Sos Canales Lake) using Stable Isotope Analysis of carbon and nitrogen. Ann. Limnol. Int. J. Limnol. 2016, 52, 401-412. [CrossRef]

41. Giussani, G.; de Bernardi, R. Food selectivity in Coregonus sp. of Lago Maggiore: An energetical approach. Mem. Ist. Ital. Idrobiol. 1977, 34, 121-130.

42. Coulas, R.A.; Macisaac, H.J.; Dunlop, W. Selective predation on an introduced zooplankter (Bythotrephes cederstroemi) by lake herring (Coregonus artedii) in Harp Lake, Ontario. Freshwater Biol. 1998, 40, 343-355. [CrossRef] 
43. Manca, M.; Vijverberg, J.; Polishchuk, L.V.; Voronov, D.A. Daphnia body size and population dynamics under predation by invertebrate and fish predators in Lago Maggiore: An approach based on contribution analysis. J. Limnol. 2008, 67, 15-21. [CrossRef]

44. Bonecker, C.C.; Azevedo, F.D.; Simões, N.R. Zooplankton body-size structure and biomass in tropical floodplain lakes: Relationship with planktivorous fishes. Acta Limnol. Bras. 2011, 23, 217-228. [CrossRef]

45. Mackas, D.L. Seasonal cycle of zooplankton off southwestern British Columbia: 1979-89. Can. J. Fish. Aquat. Sci. 1992, 49, 903-921. [CrossRef]

46. Kenitz, K.M.; Visser, A.W.; Mariani, P.; Andersen, K.H. Seasonal succession in zooplankton feeding traits reveals trophic trait coupling. Limnol. Oceanogr. 2017, 62, 1184-1197. [CrossRef]

47. Manca, M.; Rogora, M.; Salmaso, N. Inter-annual climate variability and zooplankton: Applying teleconnection indices to two deep subalpine lakes in Italy. J. Limnol. 2015, 74, 123-132. [CrossRef]

48. Manca, M.; DeMott, W.R. Response of the invertebrate predator Bythotrephes to a climate-linked increase in the duration of a refuge from fish predation. Limnol. Oceanogr. 2009, 54, 506-512. [CrossRef]

49. Manca, M. Invasions and re-emergences: An analysis of the success of Bythotrephes in Lago Maggiore (Italy). J. Limnol. 2011, 70, 76-82. [CrossRef]

50. Fadda, A.; Rawcliffe, R.; Padedda, B.M.; Luglié, A.; Sechi, N.; Camin, F.; Ziller, L.; Manca, M. Spatio-temporal dynamics of $\mathrm{C}$ and $\mathrm{N}$ isotopic signature of zooplankton: A seasonal study on a man-made lake in the Mediterranean region. Ann. Limnol. Int. J. Limnol. 2014, 50, 279-287. [CrossRef]

51. Zohary, T.; Erez, J.; Gophen, M.; Berman-Frank, I.; Stiller, M. Seasonality of stable carbon isotopes within the pelagic food web of Lake Kinneret. Limnol. Oceanogr. 1994, 39, 1030-1104. [CrossRef]

52. Leggett, M.F.; Servos, M.R.; Hesslein, R.; Johannsson, O.; Millard, E.S.; Dixon, D.G. Biogeochemical influences on the carbon isotope signatures of Lake Ontario biota. Can. J. Fish. Aquat. Sci. 2009, 56, 2211-2218. [CrossRef]

53. Leggett, M.F.; Johannsson, O.; Hesslein, R.; Dixon, D.G.; Taylor, W.D.; Servos, M.R. Influence of inorganic nitrogen cycling on the $\delta^{15} \mathrm{~N}$ of Lake Ontario biota. Can. J. Fish. Aquat. Sci. 2000, 57, 1489-1496. [CrossRef]

54. Caroni, R.; Free, G.; Visconti, A.; Manca, M. Phytoplankton functional traits and seston stable isotopes signature: A functional-based approach in a deep, subalpine lake, Lake Maggiore (N. Italy). J. Limnol. 2012, 71, 84-94. [CrossRef]

55. Geller, W.; Müller, H. The filtration apparatus of Cladocera: Filter mesh-sizes and their implications on food selectivity. Oecologia 1981, 49, 316-321. [CrossRef]

56. France, R.L.; Peters, R.H. Ecosystem differences in the trophic enrichment of ${ }^{13} \mathrm{C}$ in aquatic food webs. Can. J. Fish. Aquat. Sci. 1997, 54, 1255-1258. [CrossRef]

57. Tewfik, A.; Bell, S.S.; McCann, K.S.; Morrow, K. Predator diet and trophic position modified with altered habitat morphology. PLOS ONE 2016, 11, e0147759. [CrossRef]

58. Adams, T.S.; Sterner, R.W. The effect of dietary nitrogen content on trophic level ${ }^{15} \mathrm{~N}$ enrichment. Limnol. Oceanogr. 2000, 45, 601-607. [CrossRef]

59. Gulati, R.; Demott, W. The role of food quality for zooplankton: Remarks on the state-of-the-art, perspectives and priorities. Freshw. Biol. 1997, 38, 753-768. [CrossRef]

60. Elser, J.J.; Kyle, M.; Learned, J.; McCrackin, M.L.; Peace, A.; Steger, L. Life on the stoichiometric knife-edge: Effects of high and low food C: P ratio on growth, feeding, and respiration in three Daphnia species. Inland Waters 2016, 6, 136-146. [CrossRef]

61. Leoni, B. Zooplankton predators and prey: Body size and stable isotope to investigate the pelagic food web in a deep lake (Lake Iseo, Northern Italy). J. Limnol. 2017, 76, 85-93. [CrossRef]

62. Borgå, K.; Fisk, A.T.; Hoekstra, P.F.; Muir, D.C.G. Biological and chemical factors of importance in the bioaccumulation and trophic transfer of persistent organochlorine contaminants in arctic marine food webs. Environ. Toxicol. Chem. 2004, 23, 2367-2385. [CrossRef]

63. Walters, D.M.; Jardine, T.D.; Cade, B.S.; Kidd, K.A.; Muir, D.C.G.; Leipzig-Scott, P. Trophic magnification of organic chemicals: A global synthesis. Environ. Sci. Technol. 2016, 50, 4650-4658. [CrossRef]

(C) 2019 by the authors. Licensee MDPI, Basel, Switzerland. This article is an open access article distributed under the terms and conditions of the Creative Commons Attribution (CC BY) license (http://creativecommons.org/licenses/by/4.0/). 